Dimas Aji Purnomo dan Harliwanti Prisilia: Pengukuran Kinerja Biaya dan Waktu Pada Proyek Terminal Pariwisaya Terpadu Dengan Konsep Earned Value Analysis

\title{
PENGUKURAN KINERJA BIAYA DAN WAKTU PADA PROYEK TERMINAL PARIWISATA TERPADU DENGAN KONSEP EARNED VALUE ANALYSIS
}

\author{
Dimas Aji Purnomo ${ }^{1}$, Harliwanti Prisilia ${ }^{1}$ \\ ${ }^{1}$ Departemenen Teknik Sipil Fakultas teknik Universitas 17 Agustus 1945 Banyuwangi \\ email:dimas@untag-banyuwangi.ac.id
}

\begin{abstract}
Abstrak
Perkembangan proyek konstruksi saat ini semakin besar dan kompleks baik dari segi fisik maupun biaya. Pada hakikatnya suatu proyek mempunyai keterbatasan baik dari segi manusia, material, biaya ataupun alat. Dalam hal ini perencanaan dan pengendalian proyek diterapkan pada pembangunan Gedung Terminal Pariwisata Terpadu yang mempunyai tujuan untuk menghitung kinerja biaya dan waktu proyek. Salah satu altematifyang dapat digunakan dalam upaya pengendalian proyek ini adalah dengan metode "Earned Value". Konsep earned value merupakan salah satu alat yang digunakan dalam pengelolaan proyek yang mengintegrasikan biaya dan waktu. Berdasarkan hasil penelitian pada saat akhir peninjauan proyek pada minggu ke-20 kinerja jadwal proyek (SPI) adalah sebesar 1,19 yang artinya bahwa kinerja proyek lebih cepat dari rencana. Sedangkan dari segi kinerja biaya dapat disimpulkan bahwa biaya yang dikeluarkan lebih besar dari rencana hal tersebut ditunjukkan dengan nilai CPI sebesar 0,45. Kecenderungan kinerja proyek pada akhir peninjauan minggu ke-20, berdasarkan kondisi tersebut maka perkiraan biaya total yang akan dikeluarkan adalah sebesar $\mathrm{Rp}$ 13.463.188.080 dimana angka tersebut jauh lebih besar dari anggaran proyek sebesar Rp 12.904.970.242. Apabila ditinjau dari estimasi waktu penyelesaian proyek adalah 130 hari yang berarti lebih cepat dari waktu yang direncanakan yaitu sebesar 154 hari.
\end{abstract}

Kata kunci: perencanaan dan pengendalian, earned value, biaya, waktu.

\begin{abstract}
Nowadays, the development of construction projects are getting bigger and complex both in terms of physical and cost. In essence, a project has limitations in terms of human, materials, costs or tools. In this case, the planning and control of projects are applied to the construction of the Tourism Terminal Integrated Building which has purpose to calculate performance, cost, and time of the projects. One of alternatives that can be used in controlling this project is the "Earned Value" method. The earned value concept constitutes one of tools is used in project management that integrates with cost and time. Based on the research result at the end of the project review at the 20th week the project schedule performance (SPI) was 1.19 means that the project performance is faster than planning. While in term of cost performance can be concluded that the costs are issued are greater than planning. It is showed with score of CPI 0.45. The trend of project performance at the end of 20th week review, based on this condition, the estimate total cost to be issued is IDR 13,463,188,080 where the rate is far greater than the project budget IDR 12,904,970,242. If it is viewed from time estimation of project settlement is 130 days means that faster than time has been planned that is 145 days.
\end{abstract}

Keywords: planning and control, earned value, cost, time.

6 Jurnal Teknik WAKTU Volume 17 Nomor 01 - Januari 2019 - ISSN: 1412:1867 
Dimas Aji Purnomo dan Harliwanti Prisilia: Pengukuran Kinerja Biaya dan Waktu Pada Proyek Terminal Pariwisaya Terpadu Dengan Konsep Earned Value Analysis

\section{PENDAHULUAN}

Dalam pembangunan suatu proyek konstruksi, pengendalian biaya dan waktu proyek merupakan hal yang penting dalam proses pengelolaan manajemen proyek $(\mathrm{N}$, S, \& Kistiani, 2015). Dalam pelaksanaan suatu proyek, sangat jarang ditemui proyek yang berjalan tepat sesuai dengan rencana (Marhaendra \& Qomariyah, 2013). Umumnya mengalami keterlambatan baik waktu, biaya maupun kemajuan pekerjaan. Oleh karena itu diperlukan suatu metode untuk mangatasi hal tersebut yaitu dengan metode earned value. Konsep earned value merupakan salah satu alat yang digunakan dalam pengelolaan proyek yang mengintegrasikan biaya dan waktu (Witjaksana \& Reresi, 2012). Metode ini juga dapat digunakan untuk mendeteksi sedini mungkin apabila terjadi adanya pembengkakan biaya maupun keterlambatan yang mungkin terjadi dalam pelaksanaan proyek (Bombana, Efendi, \& Sumarsiddin, 2015).

Perkembangan proyek konstruksi saat ini semakin besar dan kompleks baik dari segi fisik maupun biaya. Ketidakpastian dan risiko sering menyebabkan keterlambatan dan pembengkakan anggaran selama eksekusi proyek (Andradea, Martens \& Vanhouckeb, 2019. Pada hakikatnya suatu proyek mempunyai keterbatasan baik dari segi manusia, material, biaya ataupun alat. Permasalahan tersebut bisa diatasi dengan menerapkan manajemen proyek mulai dari tahap awal sampai tahap akhir penyelesaian proyek.

Dalam hal ini perencanaan dan pengendalian proyek diterapkan pada pembangunan Pembangunan Gedung Terminal Pariwisata Terpadu yang memiliki harga total pekerjaan senilai Rp. 14.195.467.648,09 (sudah termasuk Pajak Pertambahan Nilai) dengan jangka waktu pelaksanaan 154 hari kalender, sedangkan dari nilai Rencana Anggaran Biaya (RAB) sebesar Rp 12.904.970.589,17. Dengan ketersediaan dana dan waktu yang terbatas diperlukan perencanaan yang matang sebelum proyek dilaksanakan. Terutama dari segi mutu pekerjaan dan pengendalian proyek yang bertujuan agar proyek dapat diselesaikan tepat waktu sesuai rencana.

Pada saat awal pelaksanaan proyek Pembangunan Gedung Terminal Pariwisata Terpadu terdapat kendala pada perubahan gambar desain dari konsultan perencana, sehingga gambar bestek yang seharusnya sudah diterima oleh pihak kontraktor mengalami kemunduran. Hal ini mengakibatkan jadwal proyek tidak sesuai dengan rencana dan secara tidak langsung menghambat proses pelaksanaan pekerjaan konstruksi pembangunan Gedung Terminal Pariwisata Terpadu. Karena adanya kendala tersebut, maka diperlukan suatu metode yang digunakan untuk menganalisa dan mencari solusi penyelesaiannya. Salah satu altematif yang dapat digunakan dalam upaya mengatasi kendala pada proyek ini adalah dengan metode "Earned Value" yang merupakan suatu metode yang digunakan pada teknik pengendalian proyek. Teknik ini merupakan metode tradisional yang diusulkan meluas tentang manajemen nilai yang diperoleh (EVM) sebagai kontrol proyek (Kerkhove \& Vanhoucke, 2016). Konsep earned value merupakan salah satu alat yang digunakan dalam pengelolaaan proyek yang mengintegrasikan biaya dan waktu.

Konsep earned value menyajikan tiga dimensi yaitu penyelesaian fisik dari proyek (The percent complete) yang mencerminkan rencana penyerapan biaya (budgeted cost), biaya aktual yang sudah dikeluarkan serta apa yang didapatkan dari apa biaya yang sudah dikeluarkan (Earned Value). Untuk itu, penelitian ini menggunakan Earned Value sebagai metode pengendalian untuk mengatasi permasalahan pada Proyek Pembangunan Gedung Terminal Pariwisata Terpadu. Variable PV, EV, dan AC masing-masing adalah biaya pekerjaan yang dijadwalkan (BCWS), biaya yang dianggarkan dari pekerjaan yang dilakukan (BCWP), dan biaya aktual pekerjaan yang dilakukan (ACWP) (Chen, \& Chen Lin, 2015). 
Dimas Aji Purnomo dan Harliwanti Prisilia: Pengukuran Kinerja Biaya dan Waktu Pada Proyek Terminal Pariwisaya Terpadu Dengan Konsep Earned Value Analysis

\section{METODE}

Konsep earned value

Secara umum earned value menggambarkan nilai pekerjaan secara actual sudah selesai pada saat tertentu. Konsep ini biasa diwakili oleh variable EV (earned value), yaitu biaya yang dianggarkan untuk pekerjaan yang sudah dikerjakan. Ada bermacam-macam variabel yang bisa digunakan untuk mengevaluasi performansi proyek pada saat tertentu, yaitu : AC (actual cost) atau disebut juga dengan ACWP (actual cost of work performed), EV (earned value) disebut juga dengan BCWP (budgeted cost of work performed) dan PV dengan istilah BCWS (Budgeted Cost of Work Scheduled) (Santosa, 2013). Langkahlangkah yang dilakukan pada penelitian ini sebagai berikut:

a. Pengumpulan Data Proyek

Pengumpulan data proyek tahap ini adalah mengumpulkan data-data yang ada pada proyek seperti kurva $\mathrm{S}$, rencana anggaran biaya (RAB), laporan bulanan, laporan mingguan, laporan harian, dan progres proyek mingguan.

b. Actual Cost $(A C)$, Planned Value (PV), Earned Value (EV)

Setelah mendapatkan data kurva $S$ dan Rencana Anggaran Biaya (RAB) maka dihitung nilai $A C$ (Actual Cost), $E V$ (Earned Value), PV (Planned Value).

c. Analisa Kinerja Proyek

Setelah nilai AC, EV dan PV diketahui maka dilakukan perhitungan untuk menghitung Schedule Performance Index (SPI), Cost Performance Index
(CPI), Schedule varians (SV), Cost Varians $(\mathrm{CV})$.

d. Analisa Perkiraan akhir Proyek Analisa Perkiraan akhir Proyek dihitung setelah perhitungan SPI, CPI, SV dan $\mathrm{CV}$ selesai dihitung. Kemudian dilanjutkan dengan menghitung indeks kemungkinan perkiraan (TCPI), biaya untuk pekerjaan tersisa (ETC), dan perkiraan total biaya akhir proyek (EAC).

e. Kesimpulan

Setelah melakukan perhitungan TCPI, ETC, EAC, kemudian dilakukan pembahasan tentang kesimpulan. Kesimpulan merupakan jawaban dari tujuan penelitian dan selanjutnya dapat membuat saran dan masukan terkait kinerja proyek.

\section{HASIL DAN PEMBAHASAN}

Analisa Kinerja Proyek

Untuk mendapatkan nilai earned value dan planned value yang pertama kali dilakukan adalah meninjau kurva s suatu proyek. Dalam kurva $\mathrm{s}$ ini bisa dilihat prosentase rencana tiap item pekerjaan. Anggaran pokok tersebut apabila dikalikan dengan nilai prosentase rencana disebut dengan planned value sedangkan earned value adalah nilai prosentase realisasi yang di kalikan dengan nilai anggaran proyek. Metode earned value dapat memperkirakan progres periode selanjutnya serta memberikan informasi mengenai posisi kemajuan proyek(Husen, 2011). Dibawah ini contoh perhitungan pada minggu ke 19 dan 20 yang disajikan pada tabel 1.

Tabel 1. Perhitungan minggu ke 19 sampai dengan minggu ke 20

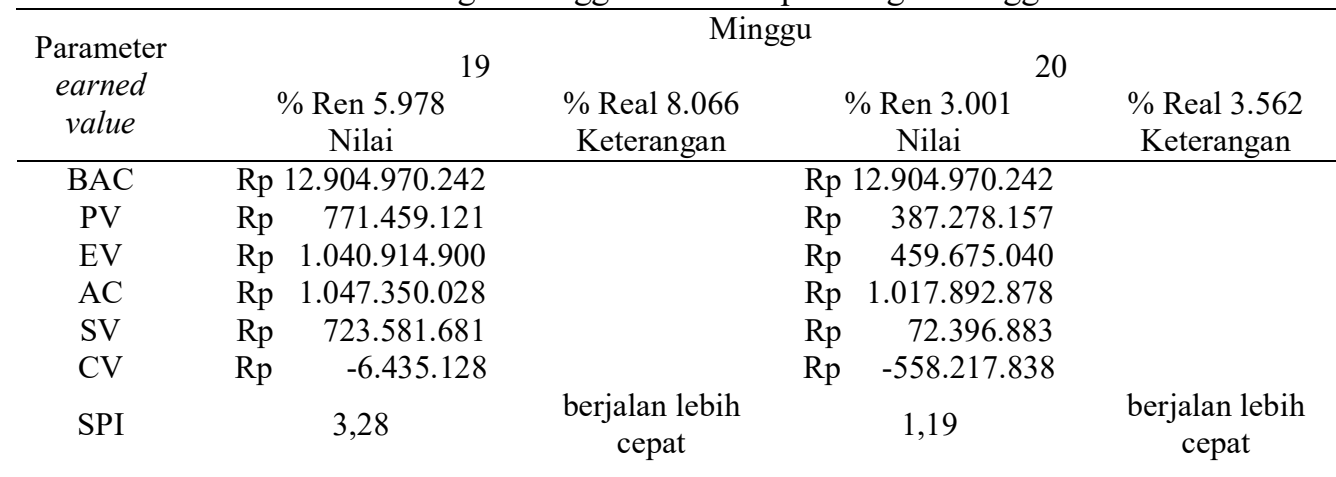


Dimas Aji Purnomo dan Harliwanti Prisilia: Pengukuran Kinerja Biaya dan Waktu Pada Proyek Terminal Pariwisaya Terpadu Dengan Konsep Earned Value Analysis

\begin{tabular}{|c|c|c|c|c|}
\hline CPI & 0,99 & $\begin{array}{c}\text { pengeluaran } \\
\text { proyek lebih } \\
\text { besar }\end{array}$ & 0,45 & $\begin{array}{l}\text { pengeluaran } \\
\text { proyek lebih } \\
\text { besar }\end{array}$ \\
\hline EAC & & & 13.463 .188 .080 & $\begin{array}{l}\text { Biaya lebih } \\
\text { besar pada } \\
\text { akhir proyek }\end{array}$ \\
\hline $\mathrm{TE}$ & & & 130 & $\begin{array}{c}24 \text { hari lebih } \\
\text { cepat }\end{array}$ \\
\hline TCPI & & & 0,98 & kenaikan biaya \\
\hline
\end{tabular}

Adapun penjelasan dari tabel diatas adalah sebagai berikut :

Seperti yang dilihat pada tabel 1, kinerja proyek pada minggu ke 19 diketahui berjalan lebih cepat dari yang direncanakan, hal ini dapat dilihat pada nilai schedule varians (SV) sebesar Rp. 723.581.681 dan schedule performance index (SPI) yang lebih besar dari 1 yaitu 3,28. Diminggu ini biaya pengeluaran proyek lebih besar dari rencana dilihat dari nilai cost varians $(\mathrm{CV})$ dan cost performance index (CPI) yang lebih kecil dari 1 atau nilai actual cost lebih besar dari pada nilai earned value. Sedangkan kinerja proyek pada minggu ke 20 diketahui berjalan lebih cepat dari yang direncanakan, hal ini dapat dilihat pada nilai schedule varians (SV) sebesar Rp. 72.396 .883 dan schedule performance index (SPI) yang lebih besar dari 1 yaitu 1,19. Diminggu ini biaya pengeluaran proyek lebih kecil dari rencana dilihat dari nilai cost varians (CV) dan cost performance index (CPI) yang lebih kecil dari 1 atau nilai actual cost lebih besar dari pada nilai Earned Value. Dengan adanya kinerja proyek seperti diatas maka waktu penyelesaian proyek (TE) dapat di perkirakan selesai dengan waktu 130 hari yang menghabiskan biaya Rp. 13.463.188.080 dimana biaya tersebut lebih besar dari nilai yang dianggarkan (BAC).
Analisa Faktor-Faktor Penyebab Kemajuan Proyek

Pada minggu ke 19 kinerja proyek lebih cepat dari rencana, biaya actual cost sebesar Rp. 1.047.350.028 lebih besar dari nilai earned value Rp. 1.040.914.900. dari penjelasan pihak kontraktor percepatan pekerjaan ini dikarenakan oleh penambahan tenaga kerja yang signifikan pada pekerjaan fire alarm, pekerjaan hydrant, pekerjaan kipas angin, pekerjaan furniture,

Pada minggu ke 20 kinerja proyek lebih cepat dari yang direncanakan serta biaya actual nya sebesar Rp. 1.017.892.878 lebih besar dari earned value Rp. 459.675.040. Biaya pengeluaran dan akhir proyek lebih besar dari rencana, namun proyek lebih cepat 24 hari dari yang direncanakan (154) dan proyek mengalami kenaikan kinerja biaya. Berdasarkan hasil wawancara dengan pihak kontraktor kinerja yang cepat pada minggu ke 20 ini dikarenakan penambahan tenaga kerja dan pembelian material berupa pasir pada pekerjaan pagar penahan, pekerjaan ground tank dan rumah pompa, pekerjaan mekanikal dan elektrikal, pekerjaan pipa air bersih, pekerjaan pengecatan serta pekerjaan penyambungan listrik. Analisa secara keseluruhan kinerja proyek selama waktu peninjauan. 
Dimas Aji Purnomo dan Harliwanti Prisilia: Pengukuran Kinerja Biaya dan Waktu Pada Proyek Terminal Pariwisaya Terpadu Dengan Konsep Earned Value Analysis

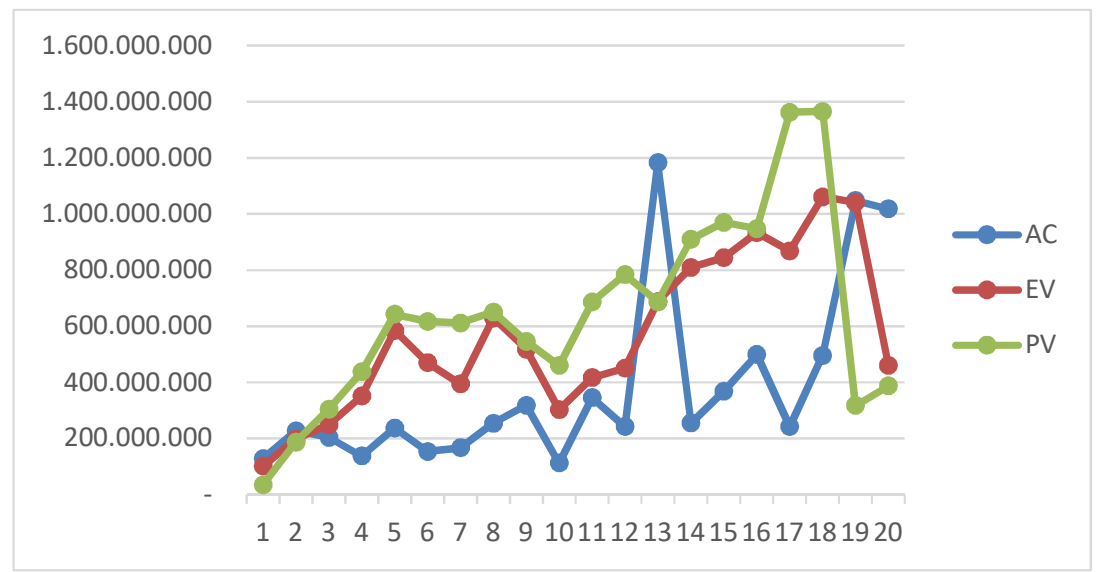

Gambar 2. Grafik hubungan antara AC, EV dan PV

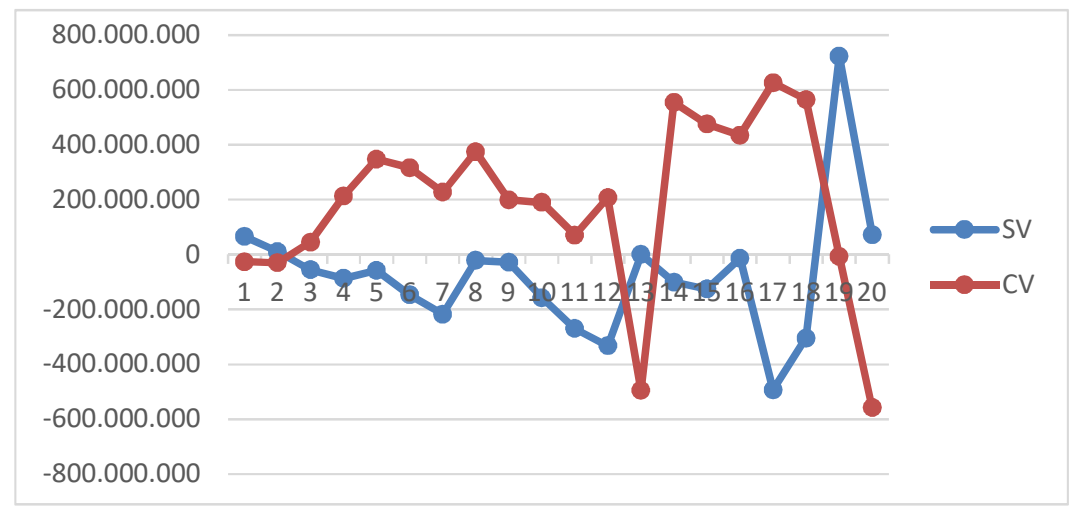

Gambar 3. Grafik hubungan antara SV dan CV

Dari Grafik 2 sampai dengan grafik 3, dapat diketahui bahwa dari segi waktu kinerja proyek untuk minggu ke-1, ke-2, ke-13, ke-19 dan ke-20 berjalan lebih cepat dari yang direncanakan. Hal tersebut bisa dilihat dari nilai Earned Value yang lebih besar dari nilai Planned Value serta nilai SPI yang lebih besar dari 1 dikarenakan ada penambahan kegiatan proyek yang semula dikerjakan di minggu akhir dikerjakan di minggu awal sehingga mengakibatkan penambahan tenaga kerja dan pembelian material proyek seperti pasir, kerikil. Akan tetapi pada minggu ke-3, ke-4, ke-5, ke-6, ke-7, ke-8, ke-9, ke-10, ke-11, ke-12, k-14, ke-15, ke-16, ke-17 dan ke-18 nilai Planned Value lebih besar dari Earned Value. Hal tersebut menunjukkan bahwa proyek pada minggu tersebut cenderung lambat dari yang direncanakan dikarenakan kegiatan proyek tersebut sudah dikerjakan diminggu sebelumnya yang mengakibatkan aktivitas proyek kecil.

Sedangkan apabila dilihat dari segi biaya, untuk minggu ke-3, ke-4, ke-5, ke-6, ke-7, ke-8, ke-9, ke-10, ke-11, ke-12, k-14, ke-15, ke-16, ke-17 dan ke-18 biaya pengeluaran proyek lebih kecil dari rencana. Sedangkan pada minggu ke-1, ke2, ke-13, ke-19 dan ke-20 pengeluaran biaya proyek lebih besar dari yang direncanakan.

Analisa Faktor-Faktor Penyebab Kemajuan Proyek

1. Minggu ke 1

Pada minggu pertama terjadi pembengkakan biaya actual cos sebesar Rp. 127.446.000 lebih besar dari nilai Earned Value $\mathrm{Rp}$. 100.916.867. Dari hasil wawancara dengan pihak kontraktor 
Dimas Aji Purnomo dan Harliwanti Prisilia: Pengukuran Kinerja Biaya dan Waktu Pada Proyek Terminal Pariwisaya Terpadu Dengan Konsep Earned Value Analysis

pembengkakan terjadi dikarenakan

pada minggu kedua yang seharusnya

untuk pekerjaan tanah, dan urugan

dikerjakan pada minggu pertama.

2. Minggu ke 2

Pada minggu ke 2 kinerja proyek berjalan dengan cepat dan biaya actual lebih besar dari yanng direncanakan yaitu sebesar Rp. 227.753.000. Berdasarkan wawancara dengan pihak kontraktor untuk aktivitas-aktivitas pekerjaan pasangan lantai dasar dan plesteran lantai dasar yang seharusnya dilakukan minggu ke 3 diselesaikan minggu ke 2.

3. Minggu ke 3

Pada minggu ke 3 kinerja proyek mengalami perlambatan dari rencana, biaya actual cost sebesar Rp. 203.449.275 lebih kecil dari nilai Earned Value sebesar Rp. 248.420.677. Dari hasil wawancara dengan pihak kontraktor hal tersebut dikarenakan material sudah tersedia pada minggu sebelumnya seperti pasir, kayu, dan multi plak sehingga pembelian bahan tidak terlalu signifikan.

4. Minggu ke 4

Pada minggu ke 4 proyek mengalami penurunan kinerja dari yang direncanakan serta biaya actual cost nya sebesar Rp. 137.462.800 lebih kecil dari Earned Value Rp. 351.144.240. biaya pengeluaran dan akhir proyek lebih kecil dari rencana, namun proyek lebih lambat 38 hari dari yang direncanakan (154) dan proyek mengalami penurunan kinerja biaya. Dari hasil wawancara dengan pihak kontraktor hal tersebut diatas dikarenakan sudah tersedia bahan meterial untuk pekerjaan struktur beton lantai satu dan pekerjaan lantai pelapis dinding lantai dasar.

5. Minggu ke 5

Pada minggu ke 5 kinerja proyek berjalan lebih lambat dari rencana, biaya actual cos sebesar Rp. 236.991.200 lebih kecil dari nilai Earned Value Rp. 584.853.251. Berdasarkan hasil wawancara dengan

pihak kontraktor hal disebut

dikarenakan pekerjaan lantai satu sudah dikerjakan pada minggu sebelumnya.

6. Minggu ke 6

Pada minggu ke 6 kinerja proyek mengalami perlambatan dari rencana, biaya actual cos sebesar Rp. 153.661.350 lebih kecil dari nilai Earned Value Rp. 469.869.967. Berdasarkan hasil wawancara dengan pihak kontraktor hal tersebut dikarenakan minggu ini digunakan untuk membeli berbagai material seperti pasir, semen, besi, kayu, dan galfalum.

7. Minggu ke 7

Pada minggu ke 7 kinerja proyek mengalami perlambatan dari rencana, biaya actual cos sebesar Rp. 167.026.600 lebih kecil dari nilai Earned Value Rp. 393.988.741. Berdasarkan hasil wawancara dengan pihak kontraktor hal tersebut diakibatkan minggu ini hanya digunakan untuk pembelian bahan material seperti paku, besi plos D10, ready mix K300 (dalam skala kecil), worlpress, bambu, pasir, besi siku, hollow, bendrat, plat baja t $1 \mathrm{~cm}$, dan kawat harmonika.

8. Minggu ke 8

Pada minggu ke 8 proyek mengalami penurunan kinerja dari yang direncanakan serta biaya actual nya sebesar 254.152.350 lebih kecil dari Earned Value Rp. 629.117.299. biaya pengeluaran dan akhir proyek lebih kecil dari rencana, namun proyek lebih lambat 5 hari dari yang direncanakan (154) dan proyek mengalami penurunan kinerja biaya. Dari penjelasan pihak kontraktor hal tersebut dikarenakan pada minggu ini hanya digunakan untuk membeli bahan-bahan seperti kayu usuk 4/6 besi polos D10, besi ulir D13, besi ulir D16, ready mix K300 (skala kecil), worlpressbambu, pasir, semen, besi ulir D18 SNI, mur, baut, engsel, rak BSW 50, triplek, besi siku, hollow, 
Dimas Aji Purnomo dan Harliwanti Prisilia: Pengukuran Kinerja Biaya dan Waktu Pada Proyek Terminal Pariwisaya Terpadu Dengan Konsep Earned Value Analysis

bendrat, plat baja t 1 , batu kali, besi 8 , cat mini $50 \mathrm{~kg}$, dan eternit.

9. Minggu ke 9

Pada minggu ke 9 kinerja proyek mengalami perlambatan dari rencana, biaya actual cos sebesar Rp. 318.353.850 lebih kecil dari nilai Earned Value Rp. 517.747.406. Dari penjelasan pihak kontraktor hal tersebut disebabkan minggu ini hanya digunakan untuk pekerjaan lantai dan pelapis dinding lantai dua.

10. Minggu ke 10

Pada minggu ke 10 kinerja proyek mengalami perlambatan dari rencana, biaya actual cos sebesar Rp. 112.088.00 lebih kecil dari nilai Earned Value Rp. 302.105.353. Dari penjelasan pihak kontraktor hal tersebut dikarenakan pada minggu ini hanya digunakan untuk membeli ready mix K500 sebesar $5 \mathrm{~m} 3$.

11. Minggu ke 11

Pada minggu ke 11 kinerja proyek mengalami perlambatan dari rencana, biaya actual cos sebesar Rp. 345.455.475 lebih kecil dari nilai Earned Value Rp. 416.314.340. Dari penjelasan pihak kontraktor hal tersebut dikarenakan minggu ini digunakan untuk pembelian beberapa bahan kayu usuk 4/6, ready mix K300 (skala kecil), worlpress, bambu, ready mix K500 (skala kecil). Selain itu minggu ini juga digunakan untuk pekerjaan struktur lantai 4 .

12. Minggu ke 12

Pada minggu ke 12 proyek mengalami penurunan kinerja dari yang direncanakan serta biaya actual nya sebesar Rp. 242.420.250 lebih kecil dari Earned Value Rp. 450.512.511. biaya pengeluaran dan akhir proyek lebih kecil dari rencana, namun proyek lebih lambat 114 hari dari yang direncanakan (154) dan proyek mengalami kenaikan kinerja biaya. Dari penjelasan pihak kontraktor hal tersebut dikarenakan minggu ini digunakan untuk membeli bahanbahan seperti multiplek, ready mix
K300 (skala kecil), worlpress, semen, mur baut, dino baut, engsel, triplek, roman, besi siku, dan hollow serta pekerjaan minggu ini pekerjaan pasangan lantai 3, pekerjaan lantai 3, strukturbeton lantai 3 dan 4, pengecatan lantai 1 dan 2 .

13. Minggu ke 13

Pada minggu ke 13 kinerja proyek berjalan sesuai dari rencana, biaya actual cos sebesar Rp. 1.183.050.500 lebih besar dari nilai Earned Value Rp. 687.963.964. Dari penjelasan pihak kontraktor minggu ini telah sesuai atau mencapai target yang telah ditentukan.

14. Minggu ke 14

Pada minggu ke 14 kinerja proyek mengalami perlambatan dari rencana, biaya actual cos sebesar Rp. 254.457.000 lebih kecil dari nilai Earned Value Rp. 809.399.734. Dari penjelasan pihak kontraktor penurunan kinerja diakibatkan oleh hanya mengerjakan pekerjaan plesteran lantai 4 dan atap selain itu juga melanjutkan pengecatan lantai 2 .

15. Minggu ke 15

Pada minggu ke 15 kinerja proyek mengalami perlambatan dari rencana, biaya actual cos sebesar Rp. 368.723.144 lebih kecil dari nilai Earned Value Rp. 844.372.203. Berdasarkan hasil wawancara dengan pihak kontraktor keterlambatan diakibatkan keadaan cuaca yang tidak mendukung sehingga pekerja tidak optimal.

16. Minggu ke 16

Pada minggu ke 16 proyek mengalami penurunan kinerja dari yang direncanakan serta biaya actual nya sebesar Rp. 498.908.944 lebih kecil dari Earned Value Rp. 933.932.696. biaya pengeluaran dan akhir proyek lebih kecil dari rencana, namun proyek lebih lambat 2 hari dari yang direncanakan (154) dan proyek mengalami penurunan kinerja biaya. Berdasarkan hasil wawancara dengan pihak kontraktor keterlambatan diakibatkan oleh ketersediaan material 
Dimas Aji Purnomo dan Harliwanti Prisilia: Pengukuran Kinerja Biaya dan Waktu Pada Proyek Terminal Pariwisaya Terpadu Dengan Konsep Earned Value Analysis

tidak terpenuhi seperti bahan kayu

usuk 4/6, paku, multiplek, dan sebagaianya

17. Minggu ke 17

Pada minggu ke 17 kinerja proyek mengalami perlambatan dari rencana, biaya actual cos sebesar Rp. 241.937.250 lebih kecil dari nilai Earned Value Rp. 868.117.348. Dari penjelasan pihak kontraktor minggu ini digunakan untuk pekerjaan mecanical electrical seperti fire alrm, hidran, dan pemasangan cctv.

18. Minggu ke 18

Pada minggu ke 18 kinerja proyek mengalami perlambatan dari rencana, biaya actual cos sebesar Rp. 495.756.950 lebih kecil dari nilai Earned Value Rp. 1.060.659.504. Dari penjelasan pihak kontraktor disebabkan karena hanya mengerjakan pekerjaan kusen pintu dan jendela, serta material sudah tersedia.

19. Minggu ke 19

Pada minggu ke 19 kinerja proyek lebih cepat dari rencana, biaya actual cos sebesar Rp. 1.047.350.028 lebih besar dari nilai Earned Value Rp. 1.040.914.900. Dari penjelasan pihak kontraktor percepatan pekerjaan ini dikarenakan oleh penambahan tenaga kerja yang signifikan.

20. Minggu ke 20

Pada minggu ke 20 kinerja proyek lebih cepat dari yang direncanakan serta biaya actual nya sebesar Rp. 1.017.892.878 lebih besar dari Earned Value Rp. 459.675.040. biaya pengeluaran dan akhir proyek lebih besar dari rencana, namun proyek lebih cepat 24 hari dari yang direncanakan (154) dan proyek mengalami kenaikan kinerja biaya.
Berdasarkan hasil wawancara dengan pihak kontraktor kinerja yang cepat pada minggu ke 20 ini dikarenakan penambahan tenaga kerja dan pembelian material berupa pasir pada pekerjaan grountank serta rumah pompa.

\section{KESIMPULAN}

Berdasarkan dari hasil observasi analisa kinerja dan perkiraan dengan metode Earned Value yang telah di laksanakan dapat ditarik kesimpulan mengenai gambaran proyek selama peninjauan, yaitu Pada saat akhir peninjauan proyek pada minggu ke-20 kinerja jadwal proyek (SPI) adalah sebesar 1,19 yang artinya bahwa kinerja proyek lebih cepat dari rencana. Sedangkan dari segi kinerja biaya dapat disimpulkan bahwa biaya yang dikeluarkan lebih besar dari rencana hal tersebut ditunjukkan dengan nilai CPI sebesar 0,45. Apabila kecenderungan kinerja proyek ada akhir peninjauan minggu ke-20, berdasarkan kondisi tersebut maka perkiraan biaya total yang akan dikeluarkan adalah sebesar Rp 13.463.188.080 dimana angka tersebut jauh lebih besar dari anggaran proyek sebesar Rp 12.904.970.242. Apabila ditinjau dari estimasi waktu penyelesaian proyek adalah 130 hari yang berarti lebih cepat dari waktu yang direncanakan yaitu sebesar 154 hari.

\section{UCAPAN TERIMA KASIH}

Penulis mengucapkan terimakasih kepada KEMERISTEKDIKTI atas dukungan dana finansial dalam riset melalui Skim PDP KEMERISTEKDIKTI 2018. Terima kasih juga penulis sampaikan kepada PT. Hariz Tiga Putra yang membantu terlaksana penelitian ini.

\section{DAFTAR PUSTAKA}

Andradea, P. A., Martensb, A., \& Vanhouckeb, M. (2019). Using real project schedule data to compare earned schedule and earned duration management project time forecasting capabilities. International Journal Automation in Construction page 68-78.

Bombana, K. A. B., Efendi, A., \& Sumarsiddin, L. O. (2015). Pengendalian Waktu Dan Biaya Pada Proyek Dengan Metode Earned Value ( Studi Kasus Pembangunan Dermaga 
Dimas Aji Purnomo dan Harliwanti Prisilia: Pengukuran Kinerja Biaya dan Waktu Pada Proyek Terminal Pariwisaya Terpadu Dengan Konsep Earned Value Analysis

Kasipute. Jurnal Iliah Teknik Mesin, 6(2), 33-42.

Chen, H.L., Chen, W.T., \& Lin, Y.L.( 2015). Earned value project management: Improving the predictive power of planned value. International Journal of Project Management pages 8

Husen, A. (2011). Manajemen Proyek: Perencanaan, penjadwalan,\& Pengendalian Proyek (Pertama). Yogyakarta: Andi Yogyakarta.

L.-P. Kerkhove a, M. Vanhoucke. (2016). Extensions of earned value management: Using the earned incentive metric to improve signal quality. International Journal of Project Management 35 (2016) 148-168.

Marhaendra, A., \& Qomariyah, S. (2013). Metode Earned value untuk analisa kinerja biaya dan waktu pelaksanaan pada Pada Proyek Pembangunan Hotel Eastparc Yogyakarta. Jurnal Teknik Sipil Universitas Sebelas Maret, 4(1), 157-164.

N, R. A., S, D. R., \& Kistiani, F. (2015). Pengendalian Biaya Dan Waktu Proyek Dengan Metode Konsep Nilai Hasil ( Earned Value ). Jurnal Teknika, 7, 671-675.

Santosa, B. (2013). Manajemen Proyek: Kosep \& Implementasi (Kedua). Yogyakarta: Graha Ilmu.

Witjaksana, B., \& Reresi, S. P. (2012). Analisis Biaya Proyek Dengan Metode Earned Value Dalam Proses Kinerja. Jurnal Teknik Sipil Untag Surabaya, 5(2), 45-56.

14 Jurnal Teknik WAKTU Volume 17 Nomor 01 - Januari 2019 - ISSN: 1412:1867 